\title{
Democratic Practice and Good Governance In Nepal
}

\author{
Girdhari Dahal, Ph.D.
}

\begin{abstract}
Nepal was declared Federal Democratic Republic after the mass movement of 2006, which was institutionalized by the Constitution of Nepal promulgated through Constitutional Assembly (CA) in 2015. The Constitution of Nepal is the people's constitution. It was a dream of people to draft their constitution from CA since 1951. Nepal has a long history of democratic movements. Democratic movements in Nepal started from the period of autocratic Rana regime back in 1940s. Nepal Praja Parisad (the first political party of Nepal) had started organized democratic movement in Nepal. Thereafter many democratic movements and revolutions took place for the establishment of federal democratic republic Nepal. Democracy and good governance are closely interrelated to one another. Democracy is called the rule of law. Legitimate government, transparent rule, accountability to the people, free and fair election, independent judiciary, and fundamental rights and duties of the people are the essential elements of good governance as well as democracy. The main objective of this paper is to explore democratic movements and the concept of good governance in Nepal. The paper also tries to analyze the role of democratic movements for democracy and the relation between democracy and good governance in Nepal.
\end{abstract}

Keywords: Constitutional Assembly, democracy, good governance. 


\section{Introduction}

Nepal is a newly declared federal democratic republic nation of $21^{\text {st }}$ century in the world. The Constitutional Assembly (CA) made the new constitution of Nepal 2015. The Constitution of Nepal is the people's constitution. It is a dream of people since 1951 to draft their own constitution through CA. Also the mandate of mass movement of 2006 was to make new constitution in Nepal through CA.

The history of democratic movement in Nepal goes back to the 1940s. The people and the civil society launched a movement against the autocratic family regime of the Ranas and established democracy in Nepal in 1951. This was a historic achievement in the entire political history of Nepal. After the establishment of democracy, people got their political rights. But, before this right of the people was fully institutionalized, again the Monarch snatched the rights of people and started partyless Panchayat System in 1961(2017 BS). This was a great betrayal for the people of Nepal. They were deprived of their own political rights achieved through the revolution. The partyless Panchayat System continued for 30 years. During this system, all the political parties were banned and the fundamental rights of the people were also seized. This tyranny from the monarchy neither could institutionalize democracy nor could it bring any significant development in the nation. Human rights and political rights of the people were highly suppressed. Political parties had continuously been struggling for the restoration of democracy since 1960. However, the political parties had not succeeded in their mission. So the civil society and the people of Nepal in the leadership of the political parties launched another mass movement for the restoration of democracy. Finally, democracy was restored with the constitutional monarch in 1990. People were made the sovereign power of the nation constitutionally 
(The Constitution Kingdom of Nepal 1990). But the monarch again turned to be autocratic and tried to rule over the sovereign people. Democracy could not be institutionalized. Development could not foster smoothly in the nation. In the meantime, the peoples' revolt was initiated by the Maoists in safeguarding the rights of people. On the other hand, the political parties in the mainstream also initiated campaign against the autocratic steps of the monarch. Finally, the political parties and CPN Maoist signed a 12 points deal and jointly conducted another mass movement for the abolishment of monarchy and the establishment of Republic Nepal (Comprehensive Peace Accord 2006). The mass movement successfully overthrew the monarchy and established democratic republic in 2006. After the successful completion of the mass movement, Comprehensive Peace Accord was signed between the government and revolutionary Maoists, Interim Constitution was formed and election was held for the CA(Dahal, 2015). The first CA was dissolved without drafting constitution and again election of second CA was held and this could successfully write a constitution for Nepal and institutionalize Federal Democratic Republic in the country (Constitution of Nepal). The Constitution of Nepal was promulgated by the CA in 2015. This was historic achievement in the entire political history of Nepal.

With different revolutions and democratic movements, it has been tried to practise good governance in Nepal. Several significant milestones have been achieved in terms of good governance after each movement. However, there is still a long way to go before the concept of good governance is fully implemented. 


\section{Objectives}

Main objective of this paper is to explore the concept of democratic movements and good governance in Nepal. It also tries to analyze main role of democratic movement for democracy and good governance in Nepal.

\section{Methodology}

This paper makes a brief description and analysis about the democratic movements and good governance of Nepal. So it is descriptive and analytical paper. It makes the best use of data from secondary sources on democratic movement and good governance in Nepal.

\section{The Concept of Democracy}

The word 'democracy' is a Latin word composed of 'Demo' means people and 'cracy' means rule. Hence, democracy is called the rule of people. Any rule without the democratic practices is recognized as autocratic rule. In Longman Dictionary (1998) the word is defined as "Democracy is a system of government in which everyone in the country can vote to elect its members. A democratic country has a government which has been elected by the people of the country" (p. 360). This means it is a situation or system in which everyone is equal and has the right to vote, make decisions etc. (ibid). The gist of this saying is that democracy is the rule of law and order with three pillars of democracy viz. liberty, fraternity and equality.

In Nepali, democracy is referred to as Loktantra. 'Lok' means people or soul and 'Tantra' means rule or body. So, democracy can be compared with soul and body (Adhikari, 2014). The welfare of an individual as body and soul is also a democracy. As said in Veda, it is सर्वभ'तहिते रता (sarwa bhuta hite rata) i.e. eat together, live together, etc. Contrary to this Vedic principle, 
$31 \%$ of people of Nepal live below poverty line (Central Bureau of Statistics, 2012). Betterment of limited people by ignoring a larger mass is not the intention of democracy. This nature can be termed as Duryodhan prabitti i.e. self- centeredness.

Different dynasties ruled over Nepal from the ancient period to the modern age. The Gopal dynasty, Mahispalas, Kirats, Lichhavies and the Mallas ruled over Nepal until the 18th century. Then the Shah dynasty (1769-1847) and the Ranas (1847-1951) ruled over Nepal from 1847 to 1951 . Then multiparty system prevailed for a decade (1951-1960) and the partyless Panchayat system ruled for the next three decades (1961-1990) and again multiparty system has been prevailing since 1991. Among these ruling systems, the Rana regime (1846-1951) has been termed as the autocratic, tyrannical family rule in the history of Nepal. These ruling systems in the political history of Nepal constitute the political and democratic evolution of Nepal.

\section{Democratic Movement of Nepal}

The democratic movements in Nepal started during the family rule of Ranas. The credits for the invent of democratic movements in Nepal goes to Praja Parishad Party- 1937 and Nagarik Adhikar Samittee was lead by Sukraraj Shastri. Madhav Raj Joshi, the father of Sukraraj Shastri was influenced by Arya Samaj of Dayananda Saraswati while Sukraraj Shastri- one of the four martyrs of Nepal, was influenced by Vedic philosophy (Sharma, 1995). Shukraraj Shastri had also translated the Brahmasutra Bhasya into Nepali. Shukraraj Shastri and another young leader Gangalal Shrestha were arrested and imprisoned by the Ranas for giving speech on Gita philosophy at Indrachowk. Shukraraj Shastri, Dharmabhakta Mathema, Dashrath Chand and Gangalal Shrestha were sentenced to death in 1941 in accusation of the Parcha Kanda (Pamphlet Scandal). These death sentences to 
these heroic leaders of Nepal boosted the protest against the autocratic, tyrannical rule of Rana in the nation.

With the birth of Parja Parishad, Nepal witnessed different political parties in Nepal and in India. The Rastriya Congress Party was established in 1947 and Prajatantrik Congress was established in 1949 by the non-residential Nepal's in India, Puspalal established Nepal Communist Party in 22 April, 1949 (Pushpalal Smriti Pratisthan, 2013). Then the National Congress and the Democratic congress were united to form Nepali Congress in 1950.

Labors in Biratnagar Jute Mill revolted against Ranas in 1947 by organizing a strike campaign. So did the students at Tindhara Sanskrik hostel for political rights. This movement was named as Jayatu Sanskritam. All these sporadic movements against Ranas united after the Sahid Kanda of 1941. Finally, the democratic revolution in 1951 put the end of 104 years old autocratic, family rule of the Ranas. The people were free to practice their civil and political rights after the establishment of democracy in 1951 (2007 BS).

\section{Democracy in Nepal}

King Tribhuvan in 1951 declared the establishment of democracy and drafting of a new constitution through the Constituent Assembly. But the declaration for drafting constitution through the Constitutional Assembly was never put into practice. The immediate successor of King Tribhuvan, King Mahendra also did not implement the declaration of constitution drafting through the CA; he instead formulated the constitution drafting committee and promulgated the Constitution for the Kingdom of Nepal 1959. As per the provisions set in the constitution, the first general election was held in 1959. The political parties participated in the election. People elected their representatives 
and the government was also formed. However, King Mahendra dissolved the parliament, abandoned the political parties and took all the powers into his hands in 1961 by using the article 55 of the same constitution. The leaders of Nepali Congress party and the Nepal Communist Party who were against the illpractice of the King were arrested and imprisoned. The partyless Panchayet System was imposed in the nation. So the political parties again started revolting against the partyless Panchayet System (1960-1990) in different ways. Taking lessons from the previous political movements, another milestone was created in the Nepali, political history in 1980 that combined the movement of the democrats and communist parties along with their sister organizations compelled the Panchayet government to hold a referendum. The referendum was held in 1980, and concluded with $55 \%$ of the total votes in favor of amended Panchayat system and $45 \%$ in favor of the multiparty democracy (Shah, 1993). The amended Panchyat system also could not address the democratic thrusts of people of Nepal.

The communist group was organized under Sahana Pradhan in 1990. Ganeshman Shingh led the democrats group, and he was made the overall in charge of democratic movement of Nepal. The collective efforts of the political parties, a mass movement was launched in the country which abolished partyless Panchyat system and established multiparty democracy with constitutional monarchy in 1990.

\section{Restoration of Democracy in Nepal}

The 1990 constitution of the kingdom of Nepal was drafted following the mass movement of 1990. For the first time in the history of Nepal, the sovereignty of the nation was vested on people by the article two of the constitution of the Kingdom of Nepal (Ministry of Law and Parliament, Kanun Kitab Byabasta 
Smitee, 1990). After this the general election was held in 1992, mid-term election in 1995 and general election in 2000. People had expected a drastic change in the social, economic and cultural aspects of the nation following the mass movement of Nepal; however, the hope of Nepal's was just in vain. So Rastiya Janamorcha led by Baburam Bhattarai put forward 40 points demand before the government, the forty points included the agendas concerning the lives of people and issues of nationality. The then government did not pay any attention towards the forty point demands. So, the Maoist Party started armed insurgency in 1996. During the insurgency Royal massacre took place in 2002 that left none alive from King Birendra'a family. Then younger brother Gyanendra was made the new King of Nepal. King Gyanendra snatched the executive powers from the elected body into his hands by overthrowing the government led by Prime Minister Sher Bahadur Deuba. Following the incident, many governments were formed and dissolved using the article 127 of the Constitution of the Kingdom of Nepal 1990. But the King could not achieve his objectives with any of these governments, so he again formed another government of Prime Minister (PM) Sher Bahadur Deuba and dissolved that too in 2005 and started his direct rule. People were not satisfied with this act of the King and the political parties strongly disagreed the move. The parliamentary parties were continuously struggling for the restoration of the parliament whereas the revolutionary Maoists were conducting armed insurgency which they called people's war.

\section{Twelve Points Understanding}

The main target of both the parliamentarians and the revolutionary Maoists was to end autocratic rule of the monarch. Realizing the importance of the united campaigns, the seven 
parliamentary parties and the revolutionary Maoists signed the 12 points understanding to collectively conduct protest against the monarchy. The initiating point and the meeting point for the understanding were restoration of parliament and election of constituent assembly.

\section{Mass Movement 2006}

The mass movement of April, 2006 was organized jointly by the seven political parties and revolutionary Maoists with the same spirit and understanding for restoration of parliament and election of constituent assembly. Finally, the united force was successful and the King was forced to lie down on his knees and restored the parliament. The reinstated parliament heavily cut down the powers of the King and also drafted a new constitution for the interim period- the Interim Constitution in 2007. The revolutionary Maoist party also joined the legislature-parliament and government, too. The first ever election of CA in the history of Nepal was held in 2008. Then the first meeting of the constitutional assembly in 2009 formally declared Nepal as a federal republic without any bloodshed. The people's representatives elected their president and the prime minister. The first CA did many significant activities for institutionalization of peace process and changes in the nation (Baral, Dhungana \& Budhathoki, 2013). However, the CA was finally dissolved without promulgating new constitution. So the election of CA was held again in 2013. This could finally make new constitution of Nepal in 2015. This constitution is in course of implementation. The democratic movement of Nepal is going ahead in this way.

\section{History of the Constitution of Nepal}

There are more than half dozen constitutions made in the history of Nepal. First written constitution was declared by the Rana Democratic Practice... Girdhari Dahal - 26 - 
Prime Minister Mohan Shamsher Rana in 1947. But it was not implemented. It was declared only to continue Rana rule but it was not for the peoples' rights with democracy. It did not address the people's political rights as well as human rights. The political parties of Nepal did not accept it, they carried on the revolution for democracy.

Democracy was established in Nepal after the revolution of 1951. After that Late King Tribhuvan promulgated interim Constitution 1951 and also proposed for new constitution by constituent assembly. It was the second written constitution in the history of Nepal. The third constitution of Kingdom of the Nepal 1959 was announced by late King Mahendra. The fourth constitution of Nepal 1964 was announced by the late King Mahedra with partyless Panchayat system. It lasted for 30 years and came to an end along with the panchayat system. Mass movement 1990 restored democracy in Nepal and new constitution (constitution of the kingdom of Nepal 1990) was promulgated with the provision of constitutional monarchy and multi-party democracy. But unfortunately constitutional monarchy tried to turn into autocratic rule. The latest people's movement started in 2006 finally ended 240 years long Shah Dynasty in Nepal. After this movement, two CA elections have been held and the second CA could make a new constitution of Nepal 2015. It is a constitution made by the people. It has followed the norms and values of constitutionalism and good governance in Nepal. The people of Nepal have become sovereign after the people's movement of 2006.

In the constitutional history of Nepal, Constitution of Nepal 2015 is made by the peoples' representatives in CA. They were elected by the people. They had the mandate of people bestowed by the mass movement of 2006. All the other constitutions were 
made by Kings or constitution recommendation committee.

\section{CA made Constitution}

The Constitution of Nepal is the result of various mass movements and revolutions in the political and democratic history of Nepal. This constitution is also a dream of Nepali people to draft their own constitution through Constitution Assembly which sustained through a 65-year-long- struggle for democracy. This constitution has vested on the sole sovereign power of the nation on the people of Nepal. There were two Constitution Assemblies in the history of Nepal. The first CA (2008) was dissolved without drafting any constitution. The second CA (2013) could finally draft new constitution for Nepal. It is an exceptional case in the world. This constitution was totally made by people's representatives. It was passed by the chairman of CA and declared by the first president of Nepal as the representatives of the people of Nepal. So this particular constitution is also called as people's constitution. The constitution of Nepal has preamble with 35 divisions, 308 articles and 9 appendixes.

The CA was composed of 601 members. These members are comprised of representatives inclusive from several areas. During the time of declaration of the constitution of Nepal, the total CA member's were 598 in number and among them 537 members have signed the new constitution. The chairman of the constitution assembly verified it and finally the constitution was declared by the head of the state. So it is called people's constitution of Nepal.

\section{Democracy}

According to eastern philosophy, democratic norms and values are आत्मानाः प्रतक्किलान्न परेसाम न समाचरेत् Sarve Bhawntu Sukhina. On the other hand, according to western philosophy, democracy is 
liberty, equality and fraternity. Liberty means freedom of speech, publication, etc. Equality means equal rights to participate in rule and to choose representative of the government as well as of the parliament. Federal democratic republic of Nepal has been institutionalized through the promulgation of constitution of Nepal in 2015. The election of the speaker of parliament and the election of president of Nepal, Prime Minister of Nepal and the chief justice of Supreme Court have been held under the new constitution 2015. The new constitution theoretically supports the theory of good governance in Nepal. Democracy and good governance have a close relation. Democracy follows the rule of law and the rule of the law is the most essential element of good governance. Also, legitimacy of the government is another element of good governance and the most important factor of democracy.

\section{Good Governance}

In addition to the devotion for democracy, people have also been equally concerned for good governance in the nation. Good governance includes people's rule, rule of law, participatory, equitable and inclusive democracy, effective, responsive, transparent, accountable and efficient institutions (Dahal, 2011). The term 'Good Governance' is coined by United Nations Development Program (UNDP) and World Bank. UNDP defines 'Governance' as the exercise of political, economic and administrative authority in management of a country's affairs at all levels. They have defined it in new ways such as rule of law, legitimacy of the government, accountability to the people, transparent economic sector, corruptionless activities of government and non-governmental sector. Good governance is corruption-free government based on the rule of law and efficient in public sector management (Dahal, 1999). The main 
root of Good governance is Ram Rajya meaning the ideal state (Dahal, 2011). Vedic norms and values of Nepal were guided by this philosophy. It is a prospective of statesmanship in the eastern philosophy. Ram was a model King in eastern society. He was very famous and popular among the people. He even did not hesitate to send his wife to jungle to address the public voice (Ramayan). Thus, Nepal is a country which is influenced by the Vedic culture Ram Rajya as well as new term Good Governance. Governance comprises the mechanisms, processes and institutions through which all the stakeholders, viz., the state, private sector, civil society and citizens articulate their interests (Kanel, 2001: 120). Both of these concepts have the same theme, i.e. to be responsible to the people. New constitution of Nepal has tried to strengthen Ram Rajya as well as Good Governance in Nepal. The conceptual frame in figures explains in detail the qualities of good governance.

Figure 1 : Conceptual frame of good governance

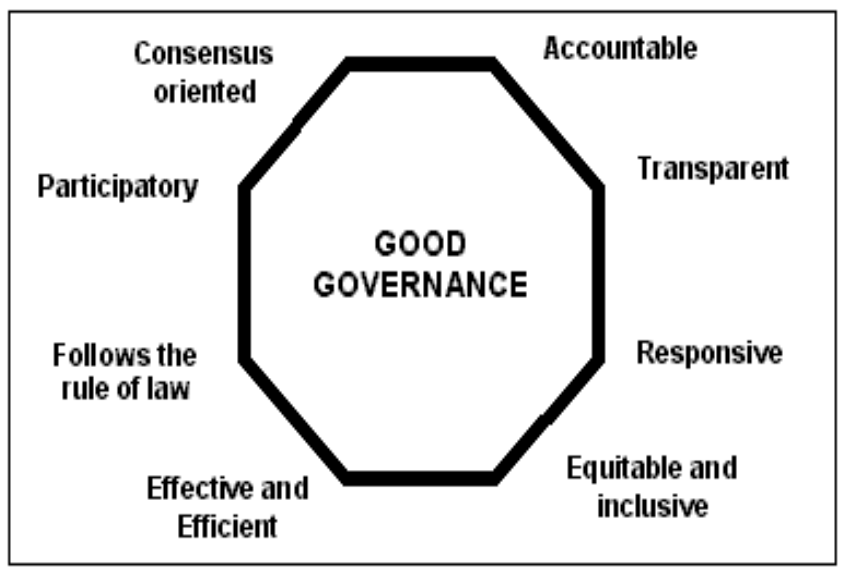

Source: gov/escap-governance.htm

Democracy and good governance are closely interrelated to one another. Democracy can be strong only if there is good governance. Governance that utilizes the capabilities of Democratic Practice... Girdhari Dahal - 30 - 
information technology maximally to achieve its objectives of good governance is now called e-Governance and sometimes it is even called e-Democracy (Kanel, 2001: 121). Thus, good governance can be realized only in democracy. Good governance and democracy are very much related to one another. The people and the civil society of Nepal have continuously fought for the establishment of democracy and good governance in the country. Finally, the country has become a federal democratic republic state. People have been the sole sovereign power of the nation (Article 2, Constitution of Nepal, 2015). The people and the civil society have continuously devoted themselves for democracy and good governance in the country.

Democracy and good governance are two sides of a coin. They go side by side. Good governance, on the one hand, strengthens democracy and democracy, on the other hand, is the pre- requisite for good governance. The success of each democratic movement is promoting good governance in Nepal. There has been improvement in the rule of law, accountability, transparency and responsibility towards people. New laws, provisions, policies and practices have been practiced to ensure good governance in Nepal. Theoretically, Nepal has made several provisions in its constitution and laws for good governance but practically people are not enjoying as much good governance as it has been written in legal documents. Besides this, the promising point is that Nepal is heading towards accelerating the pace and strengthening the quality of good governance for its people.

\section{Evolution of Good Governance after Major Democratic Movements in Nepal}

The development of good governance in Nepal can be categorized into three different phases. The first phase of evolution of good governance covers the time period from 1951-1990, the second 
phase from 1990-2006 and the third phase from 2006-present day.

The first major democratic movement in the history of modern Nepal is revolution of 1951. After this revolution, good governance started to evolve in Nepal. In the period from 19511990, public service commission was established; administrative reform commission was formed; civil service act and rule was drafted and implemented; and Supreme Court was established.

The second major democratic movement in the history of modern Nepal is mass movement of 1990. After this mass movement some other series of events for good governance were held in the period from 1990-2006. During this period, higher public administrative reform commission under the chairmanship of Prime Minister Girija Prasad Koirala was formed; and local selfgovernance act 2055 was drafted. The third phase of development of good governance in Nepal took place after the democratic mass movement of 2006. During this period, good governance act and rule was drafted and new constitution was made.

In this way, good governance gradually evolved in Nepal and it is still in the process of evolution. As a result of which there is improvement in the quality and quantity of services delivered to the people of Nepal.

\section{Challenges to Good Governance in Nepal}

Good governance is not fully exercised in Nepal. There are many hurdles to its successful implementation. Several factors are directly and indirectly responsible for the poor performance of good governance in Nepal. Corruption, no local level election for long time, lack of timely political consensus among major political parties and political instability, weak civil society, problem in bureaucracy, unregulated private sector, underdevelopment and 
unemployment and ignorance/ lack of awareness are the major challenges to good governance in Nepal. Corruption is prevalent everywhere in Nepal. Political and bureaucratic corruption is even more severe. Officials from grass root level to top level officials are involved in corruption. Corruption is the toughest challenge to good governance in Nepal. There has been no local level election for more than 15 years. The last local level election was held in 1998. Presently local bodies are operating without people's representatives and it has obstructed good governance to a large extent. Political instability has been the characteristics feature of Nepali politics. There is no political consensus among the political parties on key political issues. Even if they come to common understanding, it would take relatively longer time for them to reach up to that point. Civil society plays crucial role in promoting good governance. But civil society is not strong and organized properly in Nepal. Even the civil society is not impartial. They are highly influenced by major political parties. So they are more like sister organization of political parties. Bureaucratic system is the main implementing body of good governance, but in Nepal it has several weaknesses and loop holes. It is traditional. Bureaucrats lack to show professionalism in their work. There is the practice of red-tapism, nepotism, favoritism in the bureaucracy. In modern era, private sectors are also the major service provider to the people of a nation. But in Nepal, private sector is not thoroughly regulated by the government. They do not obey any rule or provision that is intended to regulate them. People are suffering from their malpractices and bad functioning. Underdevelopment and high level of unemployment are also negatively affecting good governance in Nepal. Also, low level of civic consciousness among the people and ignorance is creating disturbance in smooth practice of good governance in Nepal. 


\section{Conclusion}

Three major democratic movements and other movements were carried out in the political history of Nepal. As a result of these democratic movements, different nationaland locallevelelections were held at different time which helped to strengthen democracy in Nepal. Good governance also gradually developed in Nepal after each democratic movement. Good governance evolved in Nepal in three consecutive phases: from 1951-1990, 1990-2006 and 2006- present. Now, Nepal is a federal democratic republic and good governance is becoming increasingly prioritized work of the government. In this way, democratic practice and good governance are being institutionalized gradually and continue in Nepal.

\section{Acknowledgements}

I would like to express my sincere thanks to Prof. Taranath Baral, Similarly I would like to express my sincere thanks to Dr. Umanath Baral, Head of the Department, Department of Political Science, Prithvi Narayan Campus, Tribhuvan University, Pokhara, Nepal for critical suggestion.

\section{References}

Comprehensive Peace Accord (2006). The Comprehensive Peace Accord concluded between the Government of Nepal and Communist Party of Nepal (Maoist) http:// www.lawcommission.gov.nppdf.

Dahal, D.R. (1996). The Challenge Of Good Governance, Kathamandu: GDS Center for Governance and Development Studies.

Dahal, G. (2011). "Good Governance: Theoretical Perspectives" Pragyik Prabhaha, Pokhara: Bi-annual Research Journal, Year $1^{\text {st }}$,Vol.2, p 1-7. 
Dahal, G. (2015). "Constitutional Assembly of Nepal Milestone for Peace, Development and Political Stability:" KMC Journal of Interdisciplinary Studies, Vol.4.1, p.70-77.

http://www.gdrc.org/u-gov/escap-governance.htm

Joshi, B.L. and Leo, E.R. (2004). Democratic Innovations in Nepal, Kathamandu: Mandala Publication.

Nepal Government, Kanun Kitab Babastha Smittee (2015). Nepal Interim Constitution of Nepal 2007. Kathamandu.

Nepal Government, Kanun Kitab Babastha Smittee (2015). The Constitution Kingdom of Nepal 1990. Kathamandu.

Nepal Government, Kanun Kitab Babastha Smittee (2015). The Constitution of Nepal. Kathamandu.

Thapa, G.B. (1999).Democracy in Transition, Decentralization and Good Governance in Nepal (Ganga Bahadur Thapa, Ed.), Political Science Association of Nepal, FriedrichEbert-Stiftung, Germany. 